\title{
JUDICIALIZAÇÃO DA POLÍTICA E DEMOCRACIA ${ }^{1}$
}

\author{
JUDICIAL POLITICS AND DEMOCRACY
}

Vanessa Porto Alves ${ }^{2}$

\begin{abstract}
Resumo
A democracia vem passando por progressos na história. Os direitos que foram alcançados a partir do Magno documento Constitucional, agora precisam ser postos em prática pelas diversas esferas do governo, com respeito ao princípio democrático, que vai muito além de um único conceito. A judicialização da política não deve ser vista como um risco à democracia e à separação de poderes, mas sim como aliada na concretização dos preceitos constitucionais, assegurando aos brasileiros maior efetividade de seus direitos. A separação de poderes em nada interfere na atuação do judiciário em questões de cunho político, visto que não pode existir uma concorrência por poder, e sim uma mútua fiscalização entre eles, uma divisão de trabalho, que poderá ser revisada caso haja abuso de poder, contradição com o texto constitucional e grave violação de direito.
\end{abstract}

Palavras-chave: Democracia; Constituição; Direitos; Judicialização; Separação de poderes.

\section{Abstract}

Democracy has undergone great progress in history. Rights achieved trough the Constitution now need to be practiced by all governmental spheres, respecting the democratic principle, that goes beyond a mere concept. The judicializing of politics must not be seen as a danger to democracy or to the separation of powers, but as an ally in the concretion of constitutional precepts, assuring the Brazilians people greater effectiveness of theirs rights. The separation of powers in no way interferes with the judiciaries involvement in political questions, as no competition for power may exist, but rather a mutual supervision between all powers, a division of labor, that may be reviewed in case of power abuse, contradiction to Constitutional Law and grave rights violation.

Keywords: Democracy; Constitutional law; Rights; Judicialização; Separation of powers.

1 Trabalho submetido em 01/06/2013, pareceres finalizados em 10/07/2013 e 15/07/2013, aprovação comunicada em 01/08/2013.

2 Advogada inscrita na OABPR sob n. 64.661. Formada em direito pela PUCPR, especialista em direito público pela Fundação Escola do Ministério Público do Paraná. Atuante nas áreas de direito penal, direito constitucional e direito de família. Email:<porvanessa@gmail.com>. 
INTRODUÇÃO

Os preceitos da Constituição Federal de 1988 estão intimamente ligados ao advento da democracia no nosso Estado.

Com a instauração do paradigma do Estado Social de Direito (CARVALHO, 2013), que ocorreu no final da Segunda Guerra Mundial, muitos países ocidentais optaram por restringir o espaço da política majoritária, ou seja, aquela feita no âmbito das funções Executiva e Legislativa do Estado, que tem como principal objeto o voto popular, e ampliar o da justiça constitucional, tão viva no mundo contemporâneo.

O Supremo Tribunal Federal, nos últimos anos, vem desempenhando um papel na vida institucional brasileira de forma muita ativa e centralizadora no que concerne à tomada de decisões sobre questões de grande repercussão. Este fato tem gerado parabenizações e críticas de vários setores da sociedade, o que faz surgir, por certo, a necessidade de uma reflexão cuidadosa ao se abordar o tema.

De acordo com o que será tratado, a judicialização da política decorre principalmente da necessidade de pronúncia por parte dos tribunais devido a falhas no funcionamento do legislativo e do executivo, ou seja, quando estes se mostram insuficientes ou insatisfatórios. A partir daí, há uma aproximação entre o direito e a política, fazendo com que em determinadas situações fique difícil distinguir o que é um direito e o que é um interesse político.

Barroso (2013) destaca que esse fenômeno não é exclusivo do nosso país, uma vez que em variados momentos da história, em diversificadas partes do mundo, Cortes Constitucionais atuaram em questões de grande alcance político, no tocante a políticas públicas e fenômenos morais que advertem a sociedade.

É fato que atualmente se verifica uma tendente valorização da força jurisprudencial do Direito em nosso país.

Entretanto, para uma visualização adequada do fenômeno da judicialização, é necessário o entendimento de que as características do nosso Estado Democrático de Direito, principalmente a democracia, são plenamente compatíveis com essa atuação mais imponente do Judiciário. Compreender que os principais elementos da democracia, como o direito ao voto nas eleições, e os princípios da 
separação de poderes e supremacia da constituição, dentre outros que serão abordados no presente trabalho, não são contraditos pela judicialização da política, mas sim reafirmados.

Nesse contexto, Barroso (2013) defende que embora magistrados e tribunais não tenham sido eleitos diretamente pelos cidadãos, desempenham, sem dúvidas, um poder político capaz, inclusive, de invalidar atos dos poderes Executivo e Legislativo. Isto porque a democracia não pode ser resumida em princípio majoritário, indo muito além disso, na proteção da participação do cidadão e dos direitos fundamentais.

No mesmo sentido ensina Picardi (2008), ao dizer que existe uma convicção difundida de que a tarefa de adequar o direito à realidade histórico-social é também pertencente ao juiz.

Ainda, é imprescindível se fazer ante o estudo da judicialização uma análise da Constituição Federal, seus princípios e anseios, uma vez que em nosso país constituição e democracia devem caminhar juntas.

A Constituição, como será analisado, limita os poderes e vigia o jogo democrático, enquanto a democracia vem trazer o significado de soberania popular, um governo do povo (BARROSO, 2013).

A afirmação acima, apesar de aceita por muitos, consiste em ser a razão da maioria das críticas referentes à judicialização que tendem a atacar no sentido de apontar que não há uma absoluta supremacia da constituição no estado, e que impor a lei de um tribunal apenas pelo fato de ser obrigatório seguir a Constituição tende a enfraquecer a democracia. São posicionamentos daqueles que são contrários à judicialização da política.

Tal discussão leva ao tema da separação de poderes, e do sistema de Checks and Balances, que revalida a condição da Corte Constitucional não como usurpador de funções, mas sim como uma fonte de controle contra abusos políticos (SILVA, 2013).

O discernimento adequado sobre o sentido da Constituição e sua influência no Estado Democrático de Direito é de extrema importância para se vislumbrar tanto 
os argumentos favoráveis como os argumentos contrários à judicialização da política.

Com a análise dos supracitados temas, ou seja, democracia e sentido de constituição, ficará mais fácil de visualizar o porque da legitimidade e da eficácia do controle de constitucionalidade feito pela Corte Constitucional, que se acaba, muitas vezes, servindo de mais um meio de se judicializar o que para muitos só poderia ser assunto tratado pelo legislativo ou executivo.

Vianna, Burgos e Salles (2013) citam a ADIN (atual ADI) como instrumento de defesa das minorias, sendo, para tais autores, um recurso institucional estratégico de governo que acaba por, na prática, instituir o Supremo Tribunal Federal como um conselho do Estado. As decisões do Supremo garantem a homogeneidade da produção normativa estadual, fazendo prevalecer os princípios e regras de nossa Constituição.

Com a análise conjunta de democracia, separação de poderes e supremacia da Constituição, busca-se levar ao entendimento de que a judicialização da política, num Estado Democrático de Direito, pode sim, ser legítima e benéfica.

\section{A POSSIBILIDADE DA JUDICIALIZAÇÃO DA POLÍTICA EM HARMONIA COM O PRINCÍPIO DEMOCRÁTICO}

Com o fim do regime militar muitos avanços no processo democrático do Brasil foram realizados. Dentre eles podemos citar a regularidade de eleições diretas, o funcionamento do Poder Legislativo e a alternância de poder.

Após um período onde a voz do povo foi tão incisivamente calada, chegou a oportunidade esperada que interessa indubitavelmente à democracia, na direção do incentivo e do debate sobre as políticas públicas com a sociedade brasileira, fortificando e facilitando o acesso aos mecanismos de controle social (CARDOSO, 1985, p. 49).

A redemocratização do país foi uma das primeiras grandes causas da judicialização, e teve como ponto culminante a promulgação da Constituição de 1988. O Judiciário, de tempos para cá, deixou de ser um mero departamento técnico-especializado e tornou-se um verídico poder político, com capacidade para 
defender a aplicação da Constituição e das leis, inclusive confrontando com outros poderes (BARROSO, 2013).

Assim, almejou-se o início de uma nova era na vida sociopolítica nacional, conquistada com grande honra por um povo que lutou pelo término de um governo imposto, pela vida regida sob a insegurança e pela ameaça a todas as liberdades (CARDOSO, 1985, p. 50).

Em meio a tantos progressos, entretanto, a crise do Welfare State que afligia outros países na década de 70 chegou até nós, fazendo emergir o neoliberalismo, desregulamentando o mercado e querendo fazer da economia uma dimensão autônoma (SALLES; BURGOS; VIANNA, 2013). Isso gerou uma desarmonia entre as espectativas de uma democracia e de um Direito Constitucional, ficando desacreditados os partidos políticos e suas ideologias. Sem esperança no executivo e no legislativo, a petição por direitos desaguou no Judiciário, que, conforme Garapom, tornou-se o muro das lamentações do mundo moderno (SALLES; BURGOS; VIANNA, 2013).

Conforme lembrado por Cardoso (1985), ainda que diversas contrariedades políticas e disputas partidárias continuassem existindo, tudo isso em meio a tantos escândalos que envolviam representantes populares em crimes de corrupção, a Constituição de 1988 trouxe para o país novos ideais e princípios que devemos alcançar em nossa federação.

Um retrocesso a regimes ditatoriais, ausência de direitos fundamentais e proteções individuais tornaram-se mais distantes com o nascimento do Magno documento de 1988.

A nossa Constituição Federal chegou para colocar em prática os ideais há tanto tempo almejados, e, para que isso seja atendido, o dia a dia dos brasileiros precisa ser envolvido em um aprofundamento na participação democrática, somado ao desenvolvimento da consciência política e dos valores democráticos.

Para que se chegue mais próximo de se conquistar a confiança da população nesse novo regime pós-ditatorial, é imprescindível a transparência por parte da administração pública. Isto se desmembra em um principio já reconhecido em nosso estado, pela qual os cidadãos tenham garantido o acesso a informações 
sobre a execução orçamentária dos governos, assim como a disponibilização de dados que permitam o acompanhamento da execução dos contratos e processos decisórios, inclusive dos conselhos de governo e agências reguladoras (CARDOSO, 1985, p. 50).

As bases éticas e jurídico-normativas do constitucionalismo democrático são discutidas por Cittadino (MACIEL, 2013), trazendo que ao contrário do constitucionalismo liberal, marcado pela defesa do individualismo racional, a garantia limitada dos direitos civis e políticos e a clara separação de poderes, o constitucionalismo democrático prioriza valores como o da dignidade da pessoa humana e solidariedade social, ampliação da proteção dos direitos e nova concepção sobre relação entre os poderes do estado. O judiciário, nesse contexto, teria um espaço para interpretações de valore compartilhados pela sociedade e sua efetivação.

É uma vertente que defende uma democracia de maior alcance, não se limitando nos conceitos antigos e restritivos de participação nas escolhas. Parece adequada às necessidades atuais e mais compatível com o almejado pela Constituição de 1988.

Analisando, agora, aspectos históricos, situamo-nos que foram os atenienses que estabeleceram o paradigma da democracia para a antiguidade. Desenvolveram o que já se poderia chamar de uma democracia direta, que ainda no século XVIII viria oferecer a Rousseau o ideal de governo (FERREIRA FILHO, 1979, p. 30).

Ocorre que, na prática, esta democracia ateniense excluiu do povo os escravos, os metecos - descendentes de estrangeiros nascidos e radicados em Atenas - e todas as mulheres. O que sobrava com isso eram 20 mil habitantes se reunindo democraticamente e sendo considerados cidadãos para todos os efeitos, em meio a uma população real de aproximadamente 200 mil habitantes (FERREIRA FILHO, 1979, p. 30).

Observa-se, portanto, que desde os primórdios a democracia sempre foi exercida de maneira falha, ou até mesmo usada em prol de interesses particulares. 


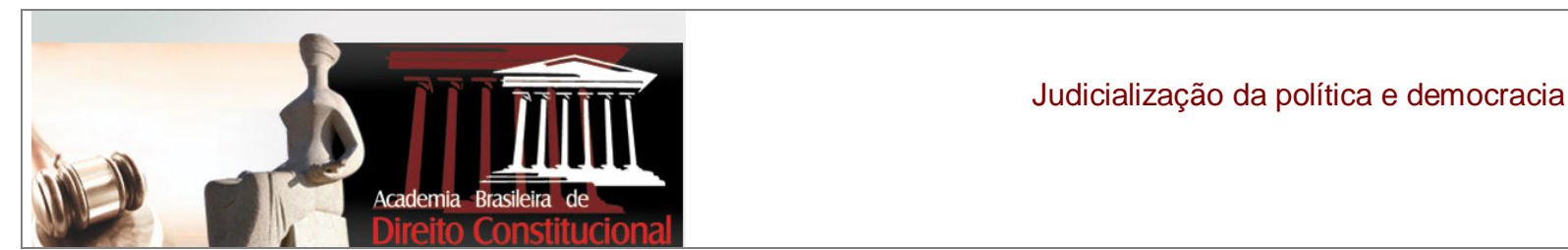

A atual Constituição Federal brasileira traz o assunto da capacidade eleitoral de votar no parágrafo primeiro do artigo 14, conforme:

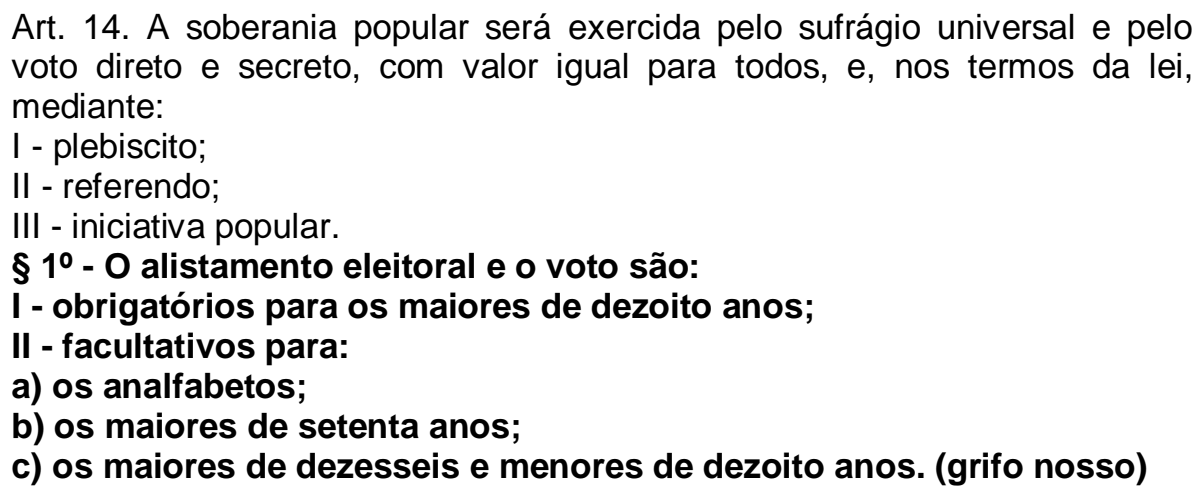

No Brasil, apenas estão expressamente impedidos de votar os estrangeiros, e os conscritos durante o período de serviço militar obrigatório. É o que dispõe o parágrafo $2^{\circ}$ do artigo 14 da Constituição Federal.

O voto dos analfabetos, maiores de 70 anos, e jovens maiores de 16 e menores de dezoito anos fica a critério do próprio individuo, que escolherá exercer ou não seu direito.

Ocorre que desde o início da elaboração da teoria democrática até os dias atuais, o princípio democrático nunca se vislumbrou realizado em sua totalidade na história. Em algum ponto, sempre houve certa relativização. Isto é, jamais todos participaram do processo político. Há as exceções implícitas, como os estrangeiros e os menores, que seriam incapacitados por razões obvias, mas existem ainda muitas classes de pessoas, em países estrangeiros na atualidade e no passado até mesmo o Brasil, que teriam condições de participar das decisões que jamais foram integrados no processo decisório democrático (FERREIRA FILHO, 1979, p. 30).

Para Waldron (2005, p. 337), um dos ideais da democracia consistem na seguinte ideia:

La democracia requiere que cuando hay desacuerdos en una sociedad en una materia sobre la que se necesita tomar una decisión común, todo hombre e mujer de la sociedad tiene el derecho de participar en términos de igualdad en la resolución de dichos desacuerdos. 
Essa seria a noção ideal de democracia: todos participando em igualdade, chegando juntos à resolução das crises. Mas, como anteriormente citado, isso nunca se realizou em nossa história, uma vez que nossa pratica de democracia ainda está arraigada em conceitos vagos e descompromissados.

Isso aclara a concepção de que os procedimentos democráticos, se não forem bem definidos e defendidos pelos poderes do Estado, em um sistema de equilíbrio de poderes no qual um cuida do outro, determinada minoria irá continuar a usar a bandeira democrática em seu único e próprio benefício, destruindo o ideal trazido pela Constituição.

A Constituição Federal brasileira vem defender o real estabelecimento e efetivação do pacto federativo, um dos principais aspectos de um país que adota o modelo democrático, de modo que se faça o desenvolvimento econômico de todos os estados, priorizando regiões menos favorecidas. Metas essas indispensáveis para que a igualdade democrática seja por fim posta em prática, uma vez que democracia significa muito mais que o direito de participação na política e nas decisões políticas e sociais do país (CARDOSO, 1985, p. 31).

A teoria democrática foi toda embasada sobre pressupostos que encontram grandes dificuldades de se realizarem no mundo contemporâneo. Por este motivo, há tempos se discute um modo eficaz de se promover a democracia. Ainda citando Cardoso, este plano é bastante árido e abstrato (CARDOSO, 1985, p. 31).

A democracia, se analisada pelo ponto de vista filosófico, seria a expressão dos valores liberdade e igualdade.

De acordo com Ferreira Filho (1979, p. 30), a atribuição de poder é um forte princípio democrático do qual todo povo deve participar do governo, em uma constante identificação entre governantes e governados. Portanto, o povo se identificava com essa participação pela eleição de seus políticos.

Os embasamentos políticos mencionados por Cardoso (1985, p. 31) remontam aos teóricos do século XVII, que tratavam a democracia basicamente como uma relação entre o indivíduo e o Estado, e de que maneira o indivíduo se protegia do estado. 
A existência do indivíduo era posta em destaque pelo pensamento democrático clássico, ou seja, queria enfatizar a ideia de que primeiro a pessoa existe sociologicamente, com seus padrões humanos inatos, e só depois existe como um ser social, vivendo em sociedade, e buscando se defender de outros seres sociais coletivos, entre os quais o próprio Estado (CARDOSO, 1985, p. 31).

A grande ligação entre indivíduo e propriedade foi o que levou a aceitação da existência de um estado. Isto porque a figura estatal teria por missão principal o seu controle de guerra, de todos contra um. Esta força (estado), quando legitimada, é justificável e aceita, não como coação, mas sim como autoridade, pois também age na defesa do proprietário (CARDOSO, 1985, p. 31).

Nos séculos XVII e XVIII o foco de uma democracia não era a questão que hoje se dá tanta relevância, ou seja, o poder participativo decisório, no qual o cidadão tem direito de participar do governo pela escolha de representantes. Também não se atentava com tanta determinação aos limites do poder do Estado (CARDOSO, 1985, p. 52).

A ênfase ficava em torno da questão da propriedade, a importância da representação tinha conotação diversa do que deveria ser pela atual concepção de democracia.

Hoje a concepção de democracia mudou.

Ensina Moreira (1995, p.178) que:

a existência de uma jurisdição constitucional, sobretudo se confiada a um tribunal específico, parece ter-se tornado nos tempos de hoje num requisito de legitimação e de credibilidade política dos regimes constitucionais democrático. A jurisdição constitucional passou a ser crescentemente considerada como elemento necessário da própria definição de Estado de direito democrático.

Por sua vez, ainda se celebra hoje que para uma democracia ser devidamente constituída, a expressão o poder emana do povo e em seu nome será exercido deve ser levada à risca (FERREIRA FILHO, 1979, p. 31). E nossa Constituição não deixa nenhuma dúvida a respeito, tratando explicitamente em seu artigo $1^{\circ}$, parágrafo único que: 
Art. $1^{\circ}$ A República Federativa do Brasil, formada pela união indissolúvel dos Estados e Municípios e do Distrito Federal, constitui-se em Estado Democrático de Direito e tem como fundamentos:

I - a soberania;

II - a cidadania;

III - a dignidade da pessoa humana;

IV - os valores sociais do trabalho e da livre iniciativa;

$\mathrm{V}$ - o pluralismo político.

Parágrafo único. Todo o poder emana do povo, que o exerce por meio de representantes eleitos ou diretamente, nos termos desta Constituição. (grifo nosso)

Extrai-se do artigo $1^{\mathrm{a}}$ da Constituição Federal do Brasil os fundamentos de uma República Federativa constituída em Estado Democrático de Direito, do que pode-se dizer ser bem aparados sobre os princípios gerais da democracia.

O parágrafo único desse mesmo artigo traz uma característica importante da nossa conquista pela democracia: todo poder emana do povo, que o exerce por meio de representantes eleitos (...).

Porém, deve-se frisar que essa é apenas uma das várias características que descansam sobre o princípio democrático, e com o passar dos anos e o nascimento de novas necessidades da sociedade, outras interpretações vão surgindo do conceito de democracia.

Mesmo que se dê credibilidade às novas noções de democracia, a afirmação de que a judicialização da política enfraquece a democracia é um dos pontos mais debatidos por quem critica este fenômeno. Justifica-se no sentido de que a judicialização usurparia o poder emanado do povo por não ser o Poder Judiciário composto por representantes eleitos.

Bachof (1987, p. 58-59) ressalta, no entanto, que é falso concluir ser o Tribunal Constitucional antidemocrático. Não se pode considerar um juiz menos orgão do povo que os demais órgãos do Estado. O juiz faz seu trabalho administrando a justiça em nome do povo.

Isso tudo ganha grande destaque porque, sob um viés constitucional, a democracia liberal pode ser resumida em três conjuntos de instituições, os quais serão analisados. 


\subsection{O sistema de eleições}

Comecemos pelo sistema de eleições para preenchimento de cargos do governo, que parece ser considerado o mais consagrado entre todos.

É principalmente nesse momento em que se dá a participação do povo no governo, quando são escolhidos por meio de voto os representantes para exercício do poder (FERREIRA FILHO, 1979, p. 36).

Certo é que a democracia liberal evoluiu do sufrágio restrito para o sufrágio universal. No entanto, sempre teve e ainda tem como fundamental a sagrada eleição (FERREIRA FILHO, 1979, p. 37).

A eleição é vista por muitos como principal característica de um país democrático, o que levaria a argumentos limitados de que o Supremo Tribunal Federal não poderia exercer decisões em nome do povo, já que não eleito diretamente por eles. Por isso, dentre outros fatores, que a judicialização da política é tratada por muitos como um risco ao princípio democrático, e careceria de legitimidade.

No entanto, para Vilallón (1995, p. 86-87), a legitimidade dos Tribunais Constitucionais é a legitimidade da própria Constituição, sendo também a legitimidade da justiça constitucional a legitimidade da minoria frente a maioria, expressões estas da vontade geral, da vontade popular. Isto porque no meio social existem grupos determinados de pessoas - minoria - que lutam por certos direitos que Ihes são indubitavelmente devidos, mas que não são interesses da grande maioria popular. Daí a necessidade de se frisar que democracia nem sempre deve ser vista como a expressão e vontade da maioria, e sim como a democracia que ouve a todos, sem distinção.

Observa-se, então, que assim como há o posicionamento de que a eleição é primordial à democracia, o que deslegitimaria o Judiciário para apreciar certas questões de cunho político, existe, do mesmo modo, quem defenda a total 
legitimidade e importância da Corte Constitucional na efetividade da expressão das minorias, muitas vezes esquecidas ou desprezadas no Legislativo.

\title{
2.2 A separação de poderes
}

O que vem em seguida ostentando não menor importância na base democrática é a separação de poderes, instrumento fundamental para a limitação do poder do Estado.

Para Bachof (1987, p. 58), o sentido da divisão de poderes é impedir que exista concentração de poderes, o que poderia levar a abusos.

Nossa Constituição traz em seu artigo 60, parágrafo $4^{\circ}$, inciso III, que a separação de poderes não poderá ser objeto em emendas constitucionais que intentem aboli-la, pois se insere no rol de cláusulas pétreas.

Kelsen (1929, p. 152) traz uma explicação sobre a separação de poderes, na qual diz:

\begin{abstract}
[...] o verdadeiro sentido desse princípio, função do equilíbrio constitucional. Para mantê-lo na República democrática, só pode ser levado razoavelmente em conta, dentre esses diferentes significados, aquele que a expressão "divisão dos poderes"traduz melhor que a de separação, isto é, a ideia de repartição de poder entre diferentes órgãos, não tanto para isolá-los reciprocamente quanto para permitir um controle recíproco de uns sobre os outros. [...]
\end{abstract}

Para Kelsen, então, o que ocorre é uma divisão de poderes, e não uma separação resultando na ideia de isolamento de cada esfera de poder. Deve existir uma harmonia em uma divisão de tarefas.

Não faria sentido, portanto, defender a ideia de que a judicialização da política que temos visto ultimamente no Supremo Tribunal Federal ofenderia o princípio da separação de poderes.

Isto porque o Legislativo, o Executivo e o Judiciário são três poderes que partilham o exercício do poder estatal. O objetivo mais visado na realização da separação de poderes repousa na preocupação de integrar num equilíbrio as diferentes forças sociais, devidamente ponderadas. Essas forças, quando em 
equilíbrio, erguem o almejado princípio de freios e contrapesos, e é deste que se espera a garantia de liberdade, na segurança de que um cidadão não precisa temer outro cidadão por estar investido no poder, já que a fiscalização impediria dos variados tipos de excessos (FERREIRA FILHO, 1979, p. 38).

Nesse sentido está Vieira de Andrade (1995, p. 77), confirmando que mesmo quando a sentença do tribunal constitucional julga ou conclui pela inconstitucionalidade de uma norma legal, confirmando ou não a decisão do juiz a quo, o tribunal não está colocando em dúvida a função legislativa, e sim a aplicação da norma no caso concreto, sendo que muitas vezes o que é censurado é a interpretação que o juiz faz da norma, interpretação esta que pode até não corresponder totalmente à intenção do legislador, ou seja, na verdade, a questão seria que, em vários casos, o tribunal discordaria mais da sentença do que da própria norma.

Dessa forma e de outras estaria o tribunal atuando no controle do abuso de poderes, o que é compatível com um dos elementos democráticos denominado princípio da separação de poderes, num sistema de Checks and Balances - freios e contrapesos (SILVA, 2013).

Ribeiro Junior (2013) explica que, "o art. 61, § 1º, da Constituição é uma norma típica do sistema de freios e contrapesos, e como tal, visa atenuar ou elidir possíveis interferências de outros poderes em assuntos que, a priori, a Constituição deixou a cargo de um poder ou de uma autoridade".

Ou seja, a Constituição estabelece que para determinadas matérias somente uma certa autoridade terá competência e legitimidade para propor projetos de lei ou emendas constitucionais. Isso, de certa forma, dá grande poder de atuação a tal autoridade, o que pede um meio de se poder interferir no processo em caso de necessidade.

Vistos assim, a limitação de poderes imposta ao parlamento e ao governo pelo controle judicial deve ser vista como uma correção necessária, como uma humilde intenção de se restabelecer o equilíbrio frente ao aumento de poder que o legislativo e o executivo têm experimentado nas últimas décadas, a causa do crescimento de suas funções e o desaparecimento de antigos fatores de sujeição (BACHOF, 1987, p. 58). 
Logo, é falso concluir que o Tribunal Constitucional tenha se transformado no verdadeiro soberano da República Federal. Isto porque ele só pode atuar repressivamente, carecendo de qualquer iniciativa própria para a configuração política, só podendo atuar a pedido de outro orgão estatal (BACHOF, 1987, p. 59).

O controle pelos Tribunais não diminui o poder do legislativo e do executivo, e sim fortalece a autoridade dos poderes controlados (BACHOF, 1987, p. 59), sendo a judicialização fator positivo na defesa da constituição e do interesse do povo.

\subsection{A supremacia da Constituição a favor da judicialização}

A supremacia da Constituição é outro elemento a ser observado na ordem democrática.

Por trazer condensada em si a ordem jurídica fundamental e os princípios que regem o determinado estado, faz-se também a fonte do limite de todos os poderes. Ela dita a competência dos três poderes, que, para serem válidos, devem ater-se ao domínio que a constituição lhes defere, seguir os princípios que indica e a forma que prescreve (FERREIRA FILHO, 1979, p. 38).

Já para Schmitt (1931, p. 53), "Una ley no puede ser protectora de otra ley. La ley más débil no puede, naturalmente proteger o garantizar a otra que sea más sólida". Ou seja, Schmitt entende que a Constituição não poderia ostentar superioridade perante as outras leis capaz de decidir sobre a validade ou invalidade das mesmas. Esta posição não ganha muito espaço em nosso ordenamento pátrio.

Na realidade brasileira, a Constituição se apresenta como parâmetro, limite e modelo a todo o restante do ordenamento jurídico, buscando dessa forma proteger a concretização das garantias e dos direitos fundamentais nela contidos.

Eis aí a importância de um orgão que possa exercer juridicamente essa subsunção, como é o caso do nosso Supremo Tribunal Federal. Na ausência de uma Côrte Constitucional como um quarto poder autônomo, o próprio Supremo Tribunal Federal cumpre o fundamental papel de guardião da Constituição e seus preceitos, organizados para impedir o abalo nos direitos fundamentais conquistados. 
$2.4 \quad$ Igualdade jurídica

Por fim, o princípio da igualdade jurídica, a combater o arbítrio do próprio Legislador. Vem para Impor que a lei seja igual e não consinta em discriminações (FERREIRA FILHO, 1979, p. 39).

Afasta a antiga ideia do poder para poucos, usado egoisticamente em interesses singulares.

A igualdade jurídica tem fundamento Constitucional, e deve ser resguardada por todo o judiciário em situações em que seja colocada em risco.

\title{
3 DEMOCRACIA NA ATUALIDADE
}

Conforme aduz Luiz Roberto Barroso (2007, p. 44), nas últimas duas décadas do século $X X$ aparece a democracia deliberativa. Esta vem como alternativa às teorias da democracia então predominante que se resumiam a um processo de agregação de interesses particulares, cujo objetivo seria a escolha de elites governante. Em suma

\begin{abstract}
para a democracia deliberativa, o processo democrático não pode se restringir à prerrogativa popular de eleger representantes. Muito além disso, a democracia deve envolver a possibilidade efetiva de se deliberar publicamente sobre as questões a serem decididas, numa troca de argumentos que viria a racionalizar e legitimar a gestão da res publica. (BARROSO, 2007, p. 43).
\end{abstract}

A Teoria Deliberativa consiste em uma corrente dentro da Teoria Democrática que vem para preencher lacunas deixadas pelas demais, dentre elas a Teoria Liberal Pluralista, o Republicanismo Cívico, a Democracia Participativa e o Multiculturalismo (COSTA, 2013).

Para que isso se realize, a deliberação deve se dar em um contexto livre, aberto e igualitário. Todos devem ter iguais possibilidades e capacidade para influenciar e persuadir. 
É o Estado de Direito que institucionaliza os pressupostos de uma deliberação justa e eficiente, já que a existência desse Estado de Direito é requisito ou pressuposto da democracia (BARROSO, 2007, p. 44).

Entrando no campo da discussão sobre a judicialização, Barroso (2007, p. 45) defende que a democracia não é afetada pelas Cortes Constitucionais: "Não há democracia sem respeito aos direitos fundamentais. Quando as cortes constitucionais os garantem contra a vontade da maioria ou diante da sua inércia, não estão violando o princípio democrático, mas estabelecendo as condições para sua plena realização".

É o caso já comentado das minorias.

Mais uma vez, parece que o trabalho que o Supremo Tribunal Federal vem fazendo nos últimos anos está de acordo com o que a Constituição Federal espera. Não age como um intruso ou considerando-se superior aos demais poderes instituídos, mas sim como maior conhecedor técnico dos aspectos jurídicos, necessários para que se proceda com seriedade um controle de constitucionalidade ou mera defesa da Constituição.

\section{O SENTIDO DE CONSTITUIÇÃO NO ESTADO DEMOCRÁTICO DE DIREITO}

Segundo uma acepção ampla, Constituição seria a organização inteira, toda a organização do ser. Já estritamente falando, constituição seria a base ou parte essencial desta organização (ALEXANDRINO, 2011, p. 788).

Para o Direito Constitucional, a Constituição deve ser entendida como Lei Fundamental e suprema de um Estado, que tem por condão reger sua organização político-jurídica.

Como o Direito Constitucional não se desenvolve isolado de outras ciências sociais, muitas são as formas de se definir Constituição.

Para a sociologia, a Constituição poderia ser vista como uma junção de fatores reais de poderes que regem uma nação (ALEXANDRINO, 2011, p. 788). 
Schmitt (1931) concebe a Constituição no sentido político, pois para ele Constituição é fruto da decisão política fundamental tomada em certo momento, ou seja, a expressão do poder em determinado momento histórico.

Já o sentido jurídico repousa na teoria pura do direito de Kelsen, que defende uma pureza metodológica, embasada no direito como ciência, afastando qualquer elemento que não seja jurídico. Para Kelsen a Constituição deve se ater ao mundo jurídico, interpretando o direito (KELSEN, 1984, p. 18).

Na obra Teoria da Constituição, Schmitt define Constituição em sentido positivo como decisão em conjunto sobre o modo e a forma da unidade política, a qual surge mediante um ato do Poder Constituinte, que se faz valer em virtude da vontade política que o mesmo lhe dá (KELSEN, 1931, p. XXXI). A Constituição seria, segundo Schmitt, a vontade dos governantes da época. O Poder Constituinte elaboraria a constituição com base unicamente na vontade do poder predominante.

Bolingbroke (apud FERREIRA FILHO, 2007, p. 77), ainda que em 1733, no trabalho A dissertation upon parties, foi o primeiro a utilizar o termo "Constituição" no sentido de estatuto jurídico superior do Estado. Para este autor, o conceito de Constituição se reflete em um complexo de leis, instituições e costumes, advindos de alguns princípios fixos e racionais, voltados a fins de bem público e que constitui o sistema geral de acordo com o qual a comunidade aceitou a ser governada (MC ILWAIN in FERREIRA FILHO, 2007, p. 77).

O consagrado Montesquieu (apud FERREIRA FILHO, 2007, p. 78) aponta no mesmo sentido de Bolingbroke. Ensina que existe uma estreita relação entre Constituição, poder e liberdade, o que pode ser exemplificado pela constituição inglesa, que reparte o exercício do poder estatal, colocando cada uma das funções essenciais do estado sob execução de um poder independente.

Consoante a isso está a Declaração dos Direitos do Homem e do Cidadão, de 26 de agosto de 1789, que traz idêntica posição em seu artigo 16. Nele coloca-se que "toda sociedade na qual não é assegurada a garantia dos direitos do homem nem determinada a separação dos poderes não tem constituição". 
Ambos os autores (Bolingbroke e Montesquieu) apresentaram um conceito de Constituição bem afrente do que era realidade em seu tempo, altamente inserido nos ideais da Revolução Francesa, e que se faz atual nos dias de hoje.

Retomando Kelsen (1984, p. 130), este sugere que é necessário ter uma noção clara do que é Constituição para que se resolva adequadamente as garantias e os modos de garantia da Constituição frente a regularidade dos graus da ordem jurídica que Ihe são imediatamente subordinados.

Portanto, uma vez compreendido o porquê da Constituição ser a base de todo o ordenamento jurídico, respeitando-se a expressão de sua supremacia, aceitaria-se a lógica de tê-la como a norma das normas.

Já Schmitt (KELSEN, 1931, p. 33) não aceitava que a Constituição pudesse ser definida como norma das normas, e atacava a teoria Normativa do Estado de Kelsen, trazendo polêmicas envolvendo a democracia e o federalismo. Polêmicas essas muito presentes hoje ao se debater a judicialização da política e seu entrave com a democracia.

Desde então, por todas as transformações que passou, a ideia de Constituição preservou-se na de um princípio supremo, que guia toda a ordem estatal e a essência da comunidade que por ela é guiada. A Constituição é sempre o fundamento do estado (KELSEN, 1984, p. 131).

Por Tavares (in FERREIRA FILHO, 2007, p. 78) "a matéria da constituição é política, sendo a mesma com o princípio de reger o poder. No entanto, sua forma é jurídica. É a lei suprema."

E como lei suprema, é o fundamento basilar para todas as demais normas jurídicas que regem a coletividade (KELSEN, 1984, p. 131).

A concepção difundida pelo constitucionalismo, ou seja, a concepção liberal de Constituição, garante ser esta a parte essencial de uma determinada organização estatal, na direção de garantir a liberdade por meio de um estatuto do poder, isso é, por meio de uma organização jurídica que além de estruturar também limite o poder no estado.. É a constituição que garante a liberdade. A Constituição-garantia (FERREIRA FILHO, 2007, p. 77). 
Segundo Tavares (in FERREIRA FILHO, 2007, p. 79), "ela presume direitos naturais do ser humano, direitos anteriores ao estado, superiores ao poder, pois o estado e poder só têm como razão de existência a garantia de tais direitos."

É a Constituição que garante direitos aos cidadãos através da limitação do poder do estado-governo.

Para Sieyès (in FERREIRA FILHO, 2007, p. 83), quando a sociedade é formada pelo livre acordo entre os homens, para que se faça possível a realização de objetivos comuns é necessário que estes se sujeitem a um poder. Este poder deve ser constituído por homens integrados em sociedade, mas esta Constituição não importa apenas na organização do governo como também na sua limitação, visando a garantia da liberdade e dos direitos naturais.

Os homens congregados em sociedade designariam representantes extraordinários, que exercem o poder constituinte, o qual em ultima instancia pertencem ao povo, ou nação, isto é, ao grupo gerado pelo pacto social. A obra desses representantes extraordinários é a Constituição. Com base nesta é que se elegem os representantes ordinários que vão exercer o Governo. Exercê-lo de acordo com a Constituição, dentro dos limites por esta traçados (FERREIRA FILHO, 2007, p. 83).

É o documento Constitucional interpretando a vontade de toda uma sociedade de um determinado país. Os eleitos ficam subordinados aos ditames da Constituição, como meros representantes da voz do povo.

A nossa Constituição se adapta ao que é chamado por Kelsen de Constituição no sentido lato, ou seja, não contem apenas regras sobre os órgãos e os procedimentos da legislação, mas também um catálogo de direitos fundamentais dos indivíduos e de liberdades individuais. É o que se vê no artigo $5^{\circ} \mathrm{e}$ todos seu rol de incisos, por exemplo.

A lei fundamental não é, portanto, unicamente uma regra de procedimento, e sim um parâmetro a ser seguido para que leis não sejam elaboradas de modo a atentar princípios constitucionais como o da liberdade, da igualdade, da propriedade, entre outros (KELSEN, 1984, p. 132). 
5 A JUDICIALIZAÇÃO DA POLÍTICA: DISCUSSÕES E POSICIONAMENTOS

A questão da judicialização da política é um assunto que vem sendo debatido há muito tempo. O judiciário tomando frente às questões iminentemente políticas, solucionando-as com base na lei, é por muitos considerado fato ameaçador à democracia, maculando o princípio da separação dos poderes.

O que mais chama atenção nos últimos tempos é a crescente atuação do Supremo Tribunal Federal na resolução de questões polêmicas que rondam a sociedade, como foi o caso do julgamento da ADPF 54, que passou a considerar inconstitucional a interpretação segundo a qual a interrupção da gravidez de feto anencéfalo é conduta tipificada nos artigos 124, 126 e 128, incisos I e II, do Código Penal, ou mesmo a decisão da ADI 4277 juntamente à ADPF132, que reconheceu a união estável para casais do mesmo sexo. Foram decisões tomadas com fundamento na defesa dos preceitos da Constituição Federal, considerada a lei suprema.

Para parte da doutrina, como será visto a seguir, essas decisões deveriam ser exclusivamente da alçada do poder legislativo, uma vez que criam ou modificam o entendimento da lei, ao contrário, estariam em confronto com a democracia.

Toda essa discussão acaba por se deparar com o papel da constituição federal no estado democrático.

Kelsen (1984, p. 3) diz que defender a Constituição significa, no sentido original do termo, a existência de um orgão cuja função é defender a constituição contra as violações.

O Supremo Tribunal Federal vem exercendo esse papel de defensor, no qual muitas vezes é acusado de excessos e até mesmo de ativismo judicial.

Cabe aqui aclarar as diferenças existentes entre a figura da judicialização da política e a figura do ativismo judicial. Apesar de terem a mesma família-usando o termo proposto por Barroso (2013) - são de origens diferentes.

A judicialização teve sua origem relacionada à redemocratização do nosso país, que desembocou em uma constitucionalização abrangente, tendência essa iniciada com a Constituição de Portugal de 1976 e com a Constituição Espanhola de 
1978 (BARROSO, 2013). Outro fator que levou a constante presença da judicialização foi a recepção do controle de constitucionalidade pelo sistema brasileiro. Em suma, Judicializar significa que questões de teor político ou social estão sendo resolvidas pelo Poder Judiciário, e não pelo Poder Executivo e Poder Legislativo, o que seria o da praxe tradicional. No ordenamento brasileiro, a judicialização encontra espaço devido ao próprio modelo constitucional que se adotou, ou seja, em todas as vezes em que o judiciário decidiu, ele o fez porque era sua função, havia uma pretensão, subjetiva ou objetiva, extraída da própria norma constitucional, restando ao judiciário conhece-la e aplicá-la.

No caso do ativismo judicial, o que se evidencia é uma escolha do modo de como se irá interpretar a Constituição, estando presente a expansão do sentido e do alcance da norma constitucional. Isto seria uma participação muito ampla e intensa do Judiciário na concretização dos preceitos constitucionais, com uma atuação mais exacerbada dentro do território dos outros poderes (BARROSO, 2013). O ativismo judicial tem sua origem na jurisprudência norte-americana.

Frente a essa distinção, torna-se mais fácil entender que o Supremo não interfere ao acaso nas questões políticas, mas somente quando é provocado. Talvez muitos conservem uma posição mais rigorosa quanto à interferência do judiciário nas questões sociais e políticas temendo um ativismo judicial irreparável, esquecendo-se de distiguir tal fenômeno da judicialização da política, que é muito mais amena e menos intervencionista.

Bachof (1987, p. 32) relata que a lei fundamental submete também o legislativo ao controle jurídico dos tribunais, e isto é, sem dúvidas, ainda mais transcendental. Aos tribunais reservou-se a função de vigiar a constituição das leis. Essa é a função do Supremo Tribunal Federal.

Bachof, assim como Kelsen, acredita na legitimidade da atuação dos tribunais na defesa da lei maior.

Kelsen posiciona-se no sentido de que não há dúvidas quanto a necessidade de se criar um instituto por meio do qual seja controlada a constitucionalidade de certos atos do Estado, subordinado imediatamente à Constituição, em especial os atos do parlamento e do governo, de maneira que este 
controle não possa ser transferido aos órgãos cujos atos devem ser controlados (KELSEN, 1984, p. 5).

Ora, o que se quer escudar é o fato de que depositar o controle constitucional nas mãos de um tribunal neutro é muito mais seguro do que deixá-lo por conta do próprio poder que cria as normas. Deixar o legislativo rever os próprios atos, é um caminho muito incerto onde a representação do povo há tempos foi substituída por lutas de interesses partidários. Teme-se que o que esteja em jogo em diversas decisões no legislativo almeje satisfazer o interesse de determinados grupos de poder, e não o da nação.

A questão da legitimidade da jurisdição constitucional e com ela do Tribunal Constitucional como orgão máximo a exercê-la, perdeu muito o seu caráter controverso. Hoje, o que tem relevância é a questão do alcance, extensão e limites da justiça constitucional (TAVARES, 2008, p. 491).

Isso significa dizer que já se aceita a participação do Tribunal Constitucional nas questões políticas, restando o debate de quais seriam suas limitações nessa atuação.

Ademais, dizer que a justiça constitucional seria um governo composto por pessoas não representativas da sociedade, porque não conduzidas a seu cargo pelo voto popular, seria simplificar por demais o argumento democrático, firmado por aqueles que são contrários à permanência do Tribunal Constitucional (TAVARES, 2008, p. 493).

Tavares (2008, p. 471) sublinha que mesmo nas hipóteses em que atua legislativamente, suprindo a falta inconstitucional do orgão competente para a função, o Tribunal Constitucional deve seguir todo um processo próprio, que exige que a decisão final seja motivada e racional. Ele ainda cumpre comandos constitucionais. Por essas razões, há uma distância entre a atividade do Tribunal Constitucional como legislador e a caracterização política dessa atividade. Só se admitem fundamentos jurídicos, jamais de mera oportunidade. O Tribunal não estaria decidindo de acordo com suas vontades subjetivas, e sim com pressuposto nas leis, no ordenamento jurídico em sua totalidade, justificando juridicamente suas decisões. 
Se a jurisdição fosse essencialmente apolítica, seria impossível haver uma jurisdição internacional. Isso porque todo conflito jurídico é, por certo, um conflito de interesse, um conflito de poder. Ou seja, toda disputa jurídica é consequentemente uma controvérsia política (KELSEN, 1984, p. 20). Não há meio de segregar o jurídico da política, pois a política necessita do jurídico para resolver seus conflitos.

A justiça, de certa forma, sempre está à disposição para atuar na resolução dos problemas do Estado. Este mesmo chama os Tribunais para intervirem em diversas questões nas quais apenas o exercício executivo e legislativo não bastam. E isso não torna o judiciário um órgão usurpador de função, nem matérias políticas judicializadas, e isso nada infere no princípio democrático.

Assim concorda Tavares (2008, p. 462), justificando que o método jurídico não é transviado pelo fato de enfrentar questões políticas. Não há essa definição de que as decisões venham a ser formalmente jurídicas e materialmente políticas. $\mathrm{O}$ Tribunal Constitucional sempre adotará decisões de cunho jurídico, mesmo que se façam presentes aspectos políticos no curso do processo.

E essa conclusão de que só a legislação e não a jurisdição é política é tão falsa como a que considera que somente a jurisdição é uma criação geradora de direito.

Sempre que se aplica o direito, que se subsume fato à lei, há criação de posicionamento, seja ele cultural ou político.

É quase uma crença jurídica o fato de que o juiz deve se limitar à aplicação da lei mediante processos mentais lógicos e que deveria abster-se de propiciar decisões arbitrais, não podendo praticar um poder social próprio (BACHOF, 1987, p. 23).

Tem-se reconhecido que o juiz sempre teve, inclusive sob o império de um positivismo jurídico rígido, uma participação importante na criação do direito para o povo (BACHOF, 1987, p. 24).

Essa caracterização política não afasta a natureza jurídica, que permanece como condição inafastável da atividade de um Tribunal Constitucional (TAVARES, 2008, p. 482). 
Em cada decisão jurídica baseada em normas há elementos de uma decisão autêntica e originária sobre o ordenamento jurídico (BACHOF, 1987, p. 24).

Mesmo que nas motivações se observem elementos extrajurídicos, com teor político, ainda será uma decisão jurídica, pois se baseia em moldes judiciais. É a forma judicial que diferenciará a atuação da Justiça Constitucional de outras atividades de cunho meramente político (TAVARES, 2008, p. 466).

Segundo a análise de Baum (TAVARES, 2008, p. 466), o Tribunal Constitucional faz suas escolhas políticas dentro de um contexto jurídico. O contexto seria exatamente esse procedimento, essa forma de decidir, especialmente a motivação da decisão, que não pode desviar-se do direito posto.

Ainda mais decisivo têm sido as mudanças que o parlamento tem experimentado na sua posição e estrutura. Em vez da representação de todo o povo por pessoas independentes, tem-se observado o mandato vinculado aos partidos.

Isso tem dado lugar ao absolutismo parlamentarista, um absolutismo da maioria parlamentarista e dos grupos de partidos que a dominam, o que conduz inevitavelmente a uma decadência da confiança e da objetividade e neutralidade dos orgãos legislativos (BACHOF, 1987, p. 54).

Impossível deixar as decisões políticas exclusivamente sob responsabilidade do legislativo. Isso sim contraria o princípio da democracia, pois o poder estaria se concentrando nas mãos de poucos. Nesse contexto acorda Bachof (1987, p. 54):

[...] necessita também de um contrapeso, uma força que se preocupe com que ao menos os valores superiores do direito e da ordem, estabelecidos pela constituição como fundamentais, permaneçam protegidos; uma força que decida, ao mesmo tempo, com a maior autoridade possível, se em um conflito eventual esses valores tenham sido salvaguardados, assegurando 0 restabelecimento da paz jurídica.

Não se requer nenhuma argumentação o fato lógico de que seja necessário um jurista para solucionar questões jurídicas. É uma instância técnica.

Nem o legislativo nem o executivo poderiam exercem com firmeza e conhecimento jurídico a guarda da Constituição como pode o judiciário. 
Por isso, a missão política do Supremo Tribunal entende-se em relação a diretrizes políticas, e nunca ao que tange a interesses partidários ou pessoais (TAVARES, 2008, p. 467).

Ademais, o poder atuante nesse caso não pode estar comprometido com o processo legislativo, nem participar dele (BACHOF, 1987, p. 54).

Deve-se colocar em análise o criticado ativismo judicial caracterizando a atuação do Tribunal Constitucional.

Essa expressão considera a predisposição de um orgão judicial em realizar mudanças significativas na adoção da política pública traçadas por outras instituições (TAVARES, 2008, p. 478).

Só o fato de pertencer a um dos poderes do Estado não quer dizer que se trate de função política. A questão é o limite para que um dos poderes possam ser representados independentes de terem sido escolhidos democraticamente seus integrantes (TAVARES, 2008, p. 480).

Todos os poder na realidade em algum momento emanaram do povo. Quem elaborou a Constituição, que será a base do controle constitucional, foi um Poder Constituinte originário com raízes na representação popular.

Ora, é estranho se afirmar que quando o judiciário se baseia nessa mesma Constituição eleita pelo povo, está atuando isoladamente, desrespeitando a representatividade democrática.

Há uma falácia no argumento de que, não sendo escolhidos pelo povo, os membros do Tribunal Constitucional careceriam de legitimidade para exercer o poder soberano (TAVARES, 2008, p. 494).

Como ensina Rousseau (apud TAVARES, 2008, p. 497), a democracia popular pode ser contrastada por outras formas de verificação democrática, ou seja, a democracia do cidadão estaria muito mais próxima do que concebe a ideia de direitos fundamentais e não a partir da concepção segundo a qual o povo soberano limita-se apenas a assumir o lugar do monarca.

Quando o Tribunal Constitucional concretiza conceitos fluidos na Constituição, atua, nesse sentido, politicamente. Há grande carga de criação de 
direito. No entanto, o Tribunal exerce essa tarefa legitimamente, já que em toda interpretação há criação jurídica (TAVARES, 2008, p. 480).

Em nenhuma instância o juiz pode julgar e decidir sem criar teor jurídico. E isso não significa que esteja legislando.

O reconhecimento da possibilidade de anulação das leis pelo Tribunal Constitucional tem sido considerada, por alguns, uma demonstração da atuação política dessa instituição (TAVARES, 2008, p. 482).

A crise da democracia parlamentar é apresentada como uma das principais problemáticas contemporâneas, e é um dos fatores do aumento da produção do Tribunal Constitucional.

Quando determinada constituição atribui expressamente ao orgão da justiça Constitucional a decisão final sobre sua interpretação, bem como a manutenção da sua supremacia, pode-se sustentar a legitimidade dos atos da justiça Constitucional. Consoante a esse argumento, é na constituição que se dividem os poderes do estado, o que só pode ser levado a efeito por um poder que lhes seja superior, e que é o poder constituinte originário. Nessa medida, todos os poderes são democráticos, já que procedem de um mesmo ato de soberania popular que é a aprovação de uma específica ordem Constitucional, e isso independente da estrutura final que se crie entre esses poderes (TAVARES, 2008, p. 499).

Perde força a crítica à judicialização da política, porque evidente que o Supremo Tribunal tem não só competência, como também o dever de exercer sua função no sistema de freios e contrapesos, na fiscalização dos demais poderes, que também deriva da necessidade de se salvaguardar os preceitos constitucionais.

\section{CONCLUSÃO}

A figura da democracia surge em diversos momentos históricos com faces diferentes. As concepções de seus significados foram se aperfeiçoando, até chegar no entendimento de que democracia é, acima de tudo, a garantia de direitos fundamentais para todos. 
Aquela ideia limitada de que democracia é sinônimo apenas de representação popular, ideia essa fixada com maior força na atualidade, está em processo de ser superada, assim como já se superaram demais conceitos históricos sobre democracia, chegando no consenso de que o princípio democrático é formado por inúmeras características.

O princípio democrático deve caminhar junto à transparência do estado e de seus governantes, o acesso às informações sobre todos os atos do governo deve ser de fácil acesso à população. Essa transparência e acessibilidade é que devem nortear a figura da democracia, pois são imprescindíveis para revelar uma democracia eficiente e viva.

O que se deseja numa democracia é a clareza, a igualdade de direitos e a liberdade de participação em tudo que diz respeito aos direitos e deveres direcionados ao povo. Se as leis são elaboradas para que a população aja de acordo com seu conteúdo, é certo que esta mesma população possui o direito de fiscalizar - ou fazer-se fiscalizar - o poder que cria a lei.

A divisão de poderes não vislumbra criar órgãos isolados que não se comunicam entre si. A real intenção desse princípio é a interação contínua, a mútua fiscalização e a divisão de tarefas, evitando o acúmulo de poder em um só lugar e o abuso no exercício das funções.

É por isso que a atuação do judiciário é componente essencial do processo político da democracia. Apesar de ser objeto de críticas por parte de alguns estudiosos, a judicialização da política contribui para o surgimento de um padrão de interação entre os Poderes, o que em nenhum momento é prejudicial à democracia, ao contrário, reforça este instituto.

E a supremacia Constitucional é o que dá meios ao judiciário de interferir, quando provocado, evitando contrariedades ao texto constitucional e à alienação dos direitos fundamentais já assegurados. O que vem sendo chamado de judicialização da política muitas vezes não passa de simples aplicação da interpretação do conteúdo constitucional ao caso concreto levado a julgamento.

O significado de Constituição no nosso estado democrático de direito é o estabelecimento de nossas premissas básicas, princípios a serem observados por 
todo o corpo social, inclusive pelos poderes do próprio estado - executivo, legislativo e judiciário. Esse nobre documento constitucional é o acordo firmado por toda uma nação, e impõe limites e assegura direitos aos que a integram. Eis a importância de se dar um status superior a essa Lei.

A judicialização da política hoje deve ser vista como um dos suportes para a defesa da Constituição e da própria democracia, já que são frutos do exercício legítimo de um Tribunal Constitucional que também exerce sua função política, indubitavelmente, no corpo social. É, sem dúvida, legítima representação da sociedade brasileira, traduzindo em justiça os anseios do povo.

A Constituição faz a interface entre o universo político e o jurídico, em um esforço para submeter o poder às categorias que mobilizam o Direito, como a justiça, a segurança e o bem-estar social. Sua interpretação, portanto, sempre terá uma dimensão política, ainda que balizada pelas possibilidades e limites oferecidos pelo ordenamento vigente (BARROSO, 2013).

Uma vez que a Constituição decorre de uma decisão proveniente de uma assembléia constituinte convocada pela soberania popular, e tudo o que nela existe é fruto da expressão da vontade do povo, seria incoerente dizer que quando o Supremo Tribunal Federal executa o controle de constitucionalidade tendo como parâmetro as leis constitucionais, estaria ameaçando a democracia devido a ausência de representantes eleitos pelo sufrágio. Ora, a Constituição Federal é a maior representação do cidadão e dos objetivos do Estado Democrático, é a maior e a mais segura representante já eleita pela nação.

Barroso (2013) ressalta que o fundamento normativo decorre, singelamente, do fato de que a Constituição brasileira atribui expressamente esse poder ao Judiciário e, especialmente, ao Supremo Tribunal Federal. Não há usurpação de competência, nem risco à democracia. Não se faz presente em nosso sistema um ativismo inescrupuloso e ilimitado. O que temos aqui respeita, certamente, os limites da separação de poderes, mas, nem por isso, deixa que os demais poderes passem por cima do texto Constitucional, que é o contrato dos brasileiros entre si e com seus governantes, principal meio de evitar arbitrariedades e retrocessos sociais.

Os recentes abalos do poder executivo e do legislativo fortaleceu ainda mais a atuação do judiciário em questões político-sociais controvertidas, o que levou o 
Supremo a ter que atuar nessas diversas esferas, dando retorno à sociedade, que não poderia ficar inerte esperando até uma data incerta, por uma resposta que nem sempre se traduz em solução.

Não há sentido em se desejar um Supremo Tribunal Constitucional omisso. A efetividade da Constituição é de interesse de todos, e a judicialização não deve ser confundida com um ativismo que vai além dos limites previamente estipulados. Em um país como o Brasil, ainda tão maculado pela ausência de princípios básicos por parte de seus governantes, daqueles que estariam a representar a população, em que os desvios vultuosos de dinheiro público contrastam com a quantidade de miséria, não há quem queira depender de decisões isoladas advindas do Congresso Nacional ou do Poder Executivo. Uma separação de poderes tão incisiva, que repudia uma judicialização da política, esquece que sem controle mútuo não se pode defender o Brasil de sua principal miséria, a própria corrupção.

\section{REFERÊNCIAS}

ALEXANDRINO, Marcelo e Vicente de Paulo. Direito Constitucional Descomplicado. 7. ed. São Paulo: Método, 2011.

ANDRADE, Vieira José. Carlos. Legitimidade da justiça constitucional e o princípio da maioria. In: Legitimidade e legitimação da justiça constitucional. Lisboa: Coimbra, 1995.

BACHOF, Otto. Jueces y Constitución. Madrid: Civitas, 1987.

BARROSO, Luís Roberto Barroso. A Reconstrução Democrática do Direito Público no Brasil. Rio de Janeiro: Renovar, 2007.

BARROSO, Luís Roberto. Interpretação e Aplicação da Constituição. 4. ed. São Paulo: Saraiva, 2002.

BARROSO, Luis Roberto. Judicialização, ativismo social e legitimidade democrática. Disponível em: <www.oab.org.br/editora/revista/.../1235066670 174218181901.pd>. Acesso em: 07 mar. 2013.

CARDOSO, Fernando Henrique. A Democracia Necessária. 2. ed. Campinas: Papirus, 1985.

CARVALHO, Carlos Eduardo Araújo de. O futuro da natureza do Estado Democrático de Direito. Uma reconstrução paradigmática a partir dos modelos de Estado Constitucional. Disponível em: <http://jus.com.br/revista/texto/12906>. Acesso em: 05 mar. 2013.

COSTA, Denise Rezende. Democracia Deliberativa: Potencialidades e Limitações. Disponível em: <http://www.arcos.org.br/cursos/politica-e-direito/artigos/democraciadeliberativa-potencialidades-e-limitacoes.>Acesso em: 23 fev. 2013. 
FAVOREU, Louis. As Cortes Constitucionais. São Paulo: Landy, 2004.

FERREIRA FILHO, Manoel Gonçalves. A Reconstrução da Democracia. São Paulo: Saraiva, 1979.

FERREIRA FILHO, Manoel Gonçalves. A Reconstrução da Democracia. São Paulo: Saraiva, 1979.

FERREIRA FILHO, Manoel Gonçalves. O Estado de Direito e a Constituição. 4. ed. São Paulo: Saraiva, 2007.

FERREIRA FILHO, Manoel Gonçalves. O Estado de Direito e a Constituição. 4. ed. São Paulo: Saraiva, 2007.

KELSEN, Hans. ?Quien débe ser el Defensor de la Constitución? Madrid: Tecnos, 1931.

KELSEN, Hans. Garantia Jurisdicional da Constituição. Paris: Universitaires de France, 1929.

KELSEN, Hans. Teoria Pura do Direito. 6. ed. Coimbra: Armênio Armado Editor, 1984.

MACIEL, Débora Alves e Andrei Koerner. Sentido da judicialização da política: duas análises. Disponível em: <www.scielo.br/pdf/ln/n57/a06n57.pdf>. Acesso em: 14 mar. 2013.

MC ILWAIN, Charles Howard. Costituzionalismo antico e moderno, 1990. In: FERREIRA FILHO, Manoel Gonçalves. O Estado de Direito e a Constituição. 4. ed. São Paulo: Saraiva, 2007.

MOREIRA, VITAL. Princípio da maioria e princípio da constitucionalidade. In: Legitimidade e legitimação da justiça constitucional. Lisboa: Coimbra, 1995.

PICARDI, Nicola. Jurisdição e Processo. [S.I]: Forense, 2008.

RIBEIRO JÚNIOR, Ulbergue. A iniciativa popular e sua relação com as iniciativas privativasdo Presidente da República. Disponível em: <http://www.planalto.gov.br/ccivil_03/revista/Rev_72/artigos/Ubergue_rev72.htm>.

Acesso: 17 mar. 2013.

SALLES, Paula Martins; BURGOS, Marcelo Baumann; VIANNA, Luiz Wernwck. Dezessete anos da judicialização da política. Disponível em: <http://dx.doi.org/10.1590/S0103-20702007000200002>. Acesso em: 20 mar. 2013.

SCHMITT, Carl. La Defensa de la Constitución. Madrid: Labor, 1931.

SILVA, Daniel Cavalcante. "Checks and Balances" e conflitos políticos. Disponível em: <http://jus.com.br/revista/texto/19065/checks-and-balances-econflitos-politicos>. Acesso: 17 mar. 2013.

SILVA, Daniel Cavalcante. "Checks and Balances" e conflitos políticos. Disponível em: <http://jus.com.br/revista/texto/19065/checks-and-balances-econflitos-politicos>. Acesso em: 17 mar. 2013.

SILVA, José Afonso. Curso de Direito Constitucional Positivo. São Paulo: Malheiros, 2002.

TAVARES, André Ramos. Curso de Direito Constitucional. 6. ed. São Paulo: Saraiva, 2008. 


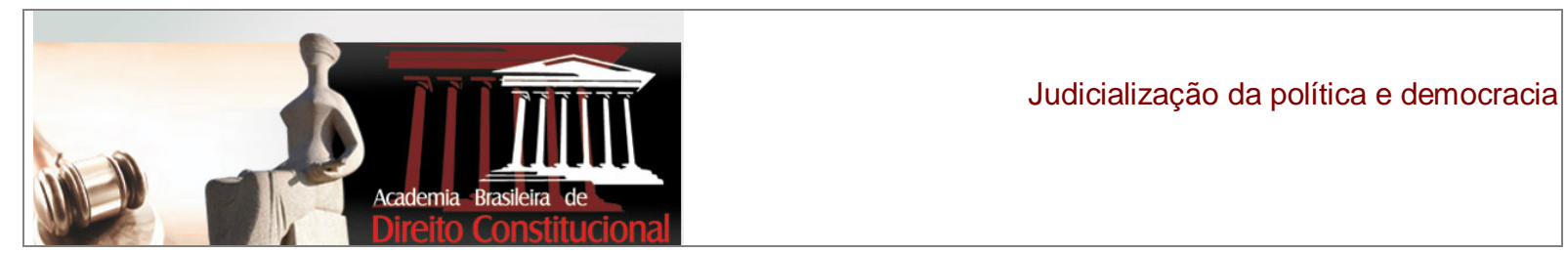

Universidade de São Paulo - USP, biblioteca digital. Disponível em: $<$ (http://www.direitoshumanos.usp.br/index.php/Documentos-anteriores-\%C3\%A0cria\%C3\%A7\%C3\%A3o-da-Sociedade-das-Na\%C3\%A7\%C3\%B5es-at\%C3\%A91919/declaracao-de-direitos-do-homem-e-do-cidadao-1789.html)> Acesso em: 17 fev. 2013.

VILALLÓN, Pedro Cruz. Legitimidade da justiça constitucional e o princípio da maioria. In: Legitimidade e legitimação da justiça constitucional. Lisboa: Coimbra, 1995.

WALDRON, Jeremy. Derecho y Desacuerdos. [ S.I.]: Marcial Pons, 2005. 